\title{
Queuing analysis using Viswalk for check-in counter: Case study of Lombok Praya International Airport
}

\author{
Sony Sulaksono Wibowo ${ }^{1, *}$, and Siti Raudhatul Fadilah ${ }^{1}$ \\ ${ }^{1}$ Bandung Institute of Technology, Study Prog. of Civil Eng., Bandung, Indonesia
}

\begin{abstract}
Queuing analysis on check-in counter in airport is required to accommodate the passenger processing facilities, such as check-in service. The purpose of this paper is to evaluate the performance of a queuing system at check-in facilities in 2 nd passenger terminal Lombok Praya International Airport in 2016 and 2036. This analysis is done by determining parameters of the queues at every check-in counter through simulations on Viswalk. Before running the simulation, the model of airport terminal must be created first. Queuing simulation starts with the traffic demand forecasting of domestic departure passenger for the next 20 years. To determine the optimal number of check-in counters, an iteration of various number is performed. Check-in services time data were adopted from previous study which became an input of the simulation using two different scenarios. The expected output are the queuing parameter and the distribution of passenger service time at each check-in counter.
\end{abstract}

\section{Introduction}

In 2016, the number of aircraft passengers at Lombok Praya International Airport was recoded reach to about 3.5 million people while the terminal's current capacity is only 3.2 million people [1]. An average number of passengers was 11,000-12,000 people per day that up about 34\% from 2015. Recently, the Lombok Praya International Airport became the second highest passenger for Eastern Area of Indonesia, among airports under PT Angkasa Pura I (API) [1]. The increasing number of passengers at Lombok Praya International Airport is related to the role of West Nusa Tenggara as a MICE tourism location (meeting, incentive, convention, and exhibition). After Lombok is designated as the world's best halal tourist sites, the flow of tourist visits continues to increase. This is predicted to lead an increase in the number of passenger, both domestic and international.

An increase in air traffic activity will affect the level of passenger service at the airport terminal. Insufficient space capacity results in density and accumulation of passengers while processing at the terminal, one of them is at check-in service. Given

\footnotetext{
${ }^{*}$ Corresponding author: sonyssw@gmail.com
} 
those problems, a good allocation management of check-in service is required which will affect the passenger's satisfaction level and cost effectiveness. It is judged by the number and time of passengers waiting in the queue and time of passenger service. Therefore, it is necessary to determine the queuing parameters of check-in service in passenger terminal of Lombok Praya International Airport. The objective of this research is to analysis the queue in check in counters using the simulation software of Viswalk. Study case of Lombok Praya International Airport was applied but the result could be extended to similar cases in other airport or other transportation terminals.

\section{Literature review}

\subsection{Queuing theory}

Basically, the queue is caused by traffic flow process, both human and/or vehicle, disturbed by the existence of a service activity that must be passed [2]. The purpose of making a queuing model is to minimize the total cost, i.e. the direct costs as the result of providing service facilities, and indirect costs which arise as the impact of people who waiting to be served. The queuing model is an important tool for obtaining a prosper management system by eliminating the queue.

To the less of connectivity, so that the passengers do not use the terminal/halte [3, 4]. There is a tendency on deregulation of transportation rules on intercity bus in some countries such as German, UK, USA, and Sweden not using terminal as transit facility. This bus transports or drops off passengers in predetermined curbside and can access city road [5].

This research aims to identify any factors affecting on quality of intercity bus terminal services. There is a great limitation on researches concerning intercity terminal so that in preparing these research indicators, there are literature studies having no cover on bus terminal $[3,4]$, it is not only caused by very limited sources, but also by transfer facilities such as interchange [3, 4]. Although in the literature study, there are broad reviews on its scope not only on terminal, but in each prepared category indicators, it has included terminal / transfer facility service quality indicator. From the literature studies, there is only Yatskiv et al. (2009) studying on intercity terminal with Regression Model analysis method [3]. From results of literature studies, there is none studying on quality of intercity bus terminal service.

The queuing system is the arrival of the customer to get service, waiting to be served if the service facility (server) is still busy, get service and then leave the system after being served. There are three components in a queue system, namely:

- Arrival or system input;

The characteristics of arrival are population size, behavior, and a statistical distribution.

- The queue discipline, or the queue itself;

Queuing characteristic include whether the number of queues, queue length, and the number of people in the queue are limited or not.

- Service facilities.

The characteristic of this component is including the design and the statistics distribution of service time.

The queue discipline shows the decision guidelines used to select individuals who enter the queue and determine who will be served first. There are three types of queuing disciplines that are commonly used. Those queue disciplines will be explained briefly below.

- First in First out (FIFO) or First Come First Served (FCFS) 
This queue discipline is very often used in transportation case, where the first person or vehicle arrives at a service counter will be served first.

- First in Last Out (FILO) or First Come Last Served (FCLS)

The second queue discipline is also quite often used in transportation case, where the first person or vehicle arrives will be served last.

- First Vacant First Served (FVFS)

This queue discipline is quite different from the two previous queue disciplines, where the first person arrives will be served by the first empty counter. In this case, only a single queue will be formed, but the number of counter may be more than one.

The queuing model is created to produce tools that can be used to estimate the performance of each process of transport activities, which related to the queue including the time and length of the queue. This model is distinguished by arrival pattern, departure pattern, and queue discipline. Distribution of arrival rate and time of arrival, as well as the departure rate and time of departure between vehicles or persons will be follow these patterns below.

- Uniform time interval pattern (assuming the arrival rate is uniform)

- Exponential-negative time interval pattern (assuming the arrival rate is follow the poisson distribution)

\subsection{Viswalk}

PTV Vissim is the leading microscopic simulation program, developed by PTV Group (Planung und Transport Verkehr AG), for modeling multimodal transport operations [4, 6]. Vissim can be used to simulate pedestrians flows and vehicular traffic, and the interaction between them. With the add-on module PTV Viswalk, it is possible to simulate large numbers of pedestrians and flows, both inside and outside buildings. Viswalk can also be used to simulate more complex pedestrian movements, for example in stadiums, train stations, and traffic intersections. By using Viswalk, analysis of route selection and the congestion points which able to happened is possible.

Viswalks is based on the social force model, developed by Helbing and Molnar as in [4], which can reproduce some aspects of human behaviour [4, 6]. The social force model is part of self-driven particle models which was introduced by Vicsek et al [6]. Self-driven particle models can be used to describe the collective motion of a groups. That group is modelled by a collection of particles where each particle is autonomous. The social force model is based on the assumption that a number of different forces act on pedestrians, resulting in a single social force that describes the pedestrian's motivation to move. The social force can either be an acceleration or deceleration force depending on the pedestrian's perceived information about the environment [4].

\section{Methodology}

This paper work can be divided into three main parts, as follows:

- Forecasting number of passengers at peak hour until 2036;

- Determining the number of check-in counters that are opened iteratively;

- Modeling and simulating the check-in service queue using Viswalk. 


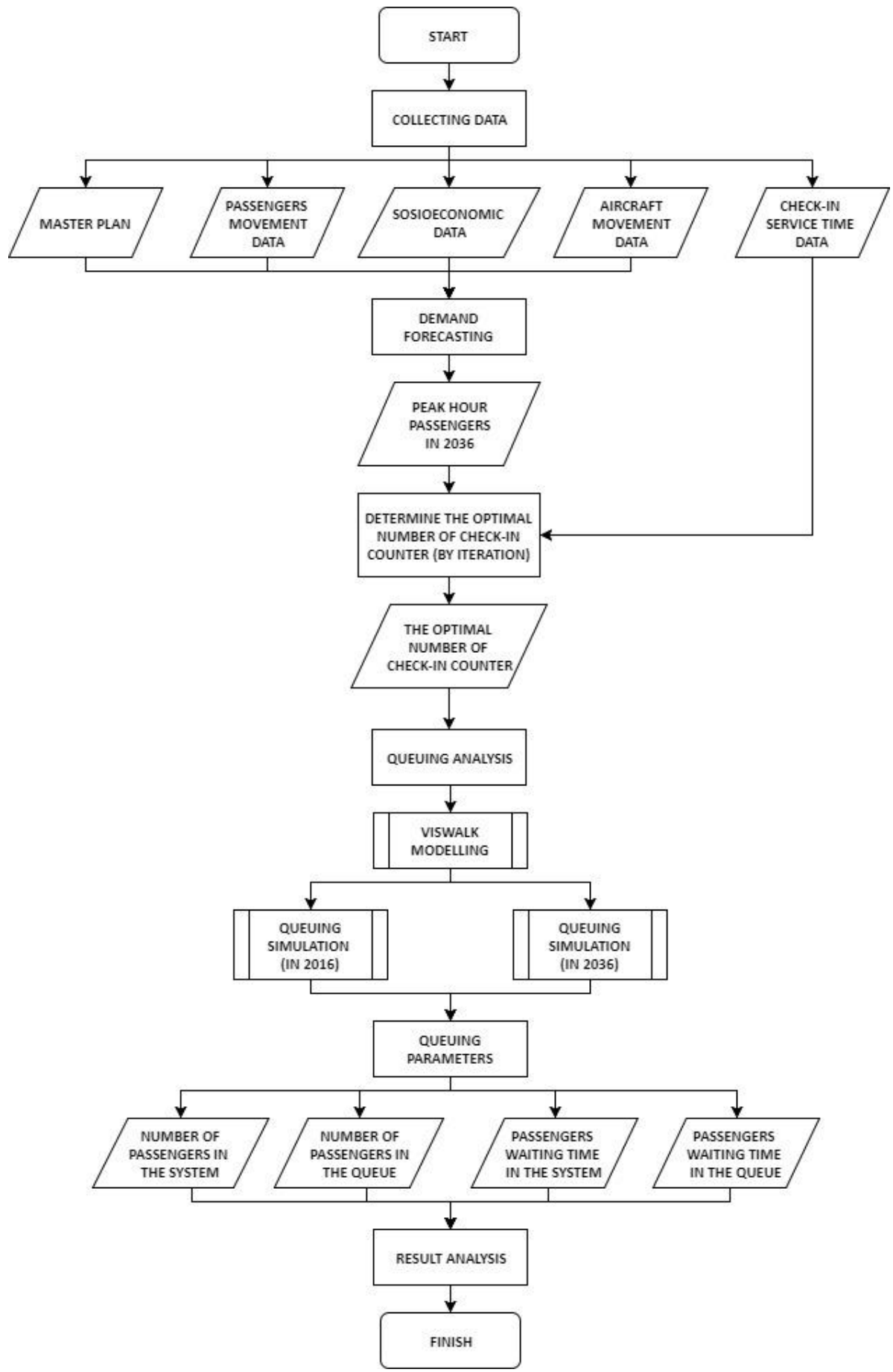

Fig.1. Flowchart of paper work

Figure 1 shows the flowchart used in this paper. In the modeling step using Viswalk, the assumptions used are: 
- The behavior of pedestrians, gender, and clothing is considered the same and does not affect modeling.

- Movement aids that are modeled only ladders and escalators, while elevators are modeled as obstacles due to software limitations.

- The speed of pedestrians when up and down stairs is considered the same.

- The movement of pedestrians on the ladder is assumed to have the same speed as the movement in the horizontal plane.

As for the queuing system itself, both in the calculation and in the modeling, there are several assumptions used, namely:

- Passenger plane only consists of direct departure passengers.

- Passengers come in one by one, i.e. no passengers come in groups.

- There is no group check-in service.

- No passengers use online check-in technology.

- Unlimited queue capacity, i.e. no passengers are missing from the system, but only wait until it can be served.

\section{Data analysis and discussion}

\subsection{Forecasting passenger movements}

The assumption used in this paper is that $2^{\text {nd }}$ passenger terminal of Lombok Praya International Airport is a domestic terminal. Therefore, the focus on this discussion is only on the departure area, especially the passenger and goods check-in areas, so that international departure data does not need to be processed. In simulating and calculating check-in queue parameters to determine the arrival rate of passengers at $2^{\text {nd }}$ passenger terminal of Lombok Praya International Airport, forecasting passenger movement is an important thing to do. The purpose of this stage is to ensure that the check-in counters provided able to accommodate the passengers' needs for the next 20 years (2016-2036). The table below shows the data of annual number of passenger from Lombok Praya International Airport.

Table 1. Annual passengers data of Lombok Praya International Airport

\begin{tabular}{|c|c|c|c|c|}
\hline \multirow{2}{*}{ Year } & \multicolumn{4}{|c|}{ The Annual Number of Passengers } \\
\cline { 2 - 5 } & \multicolumn{2}{|c|}{ Departure } & \multicolumn{2}{c|}{ Arrival } \\
\cline { 2 - 5 } & International & Domestic & International & Domestic \\
\hline 2008 & 59.336 & 470.230 & 58.947 & 467.143 \\
\hline 2009 & 78.858 & 625.406 & 65.549 & 520.164 \\
\hline 2010 & 75.861 & 605.393 & 78.593 & 625.237 \\
\hline 2011 & 90.275 & 722.234 & 94.563 & 752.786 \\
\hline 2012 & 98.580 & 789.401 & 104.401 & 829.570 \\
\hline 2013 & 107.551 & 862.184 & 116.397 & 924.058 \\
\hline 2014 & 116.531 & 935.470 & 128.421 & 1.019 .143 \\
\hline 2015 & 125.516 & 1.009 .559 & 140.415 & 1.115 .962 \\
\hline 2016 & 134.679 & 1.085 .781 & 152.435 & 1.213 .051 \\
\hline
\end{tabular}

In this paper, the boundary of the study area or commonly called hinterland that will be used is West Nusa Tenggara. This province was chosen as hinterland because it is where Lombok Praya International Airport is located and basically this airport is not a 
transit airport, but as a final destination flight. Forecasting passenger movement is done using three methods, namely exponential, linear, and econometric. The best method of representing the actual condition of the check-in queuing system of Lombok Praya International Airport will be used in further analysis. Below is the result of the calculation.

Table 2. Forecasting Passenger Movement Results

\begin{tabular}{|l|c|c|}
\hline \multirow{2}{*}{ Methods } & \multicolumn{2}{|c|}{ Domestic Departure } \\
\cline { 2 - 3 } & $\mathrm{R}^{2}$ & Number of Passengers \\
\hline Exponential & 0,9809 & 12.018 .893 \\
\hline Linear & 0,9974 & 3.121 .722 \\
\hline Econometric & 0,9898 & 3.108 .425 \\
\hline
\end{tabular}

From the table above, the linear forecasting method gives the highest $\mathrm{R}^{2}$ value compared to the other two methods. It also produces the logical and representative number of passengers for the next 20 years. So, there are 1,213,051 passengers in 2016 and increased to $3,121,722$ passengers in 2036 which shown by the graph below.

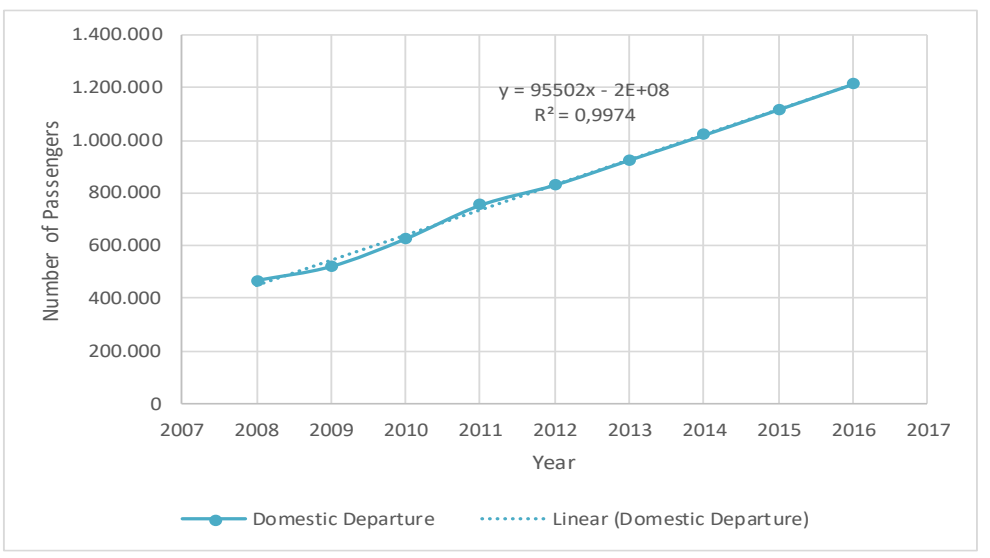

Fig. 1 Linear Forecasting Result

Next step is to calculate the daily number of passengers by dividing the annual number of passengers to the number of days in a year. It is assumed that one year consists of 365 days. Then, the data will be used in the aircraft modulation step to be distributed to all operating airlines at $2^{\text {nd }}$ passenger terminal of Lombok Praya International Airport. From website www.flightradar24.com (accessed on December, 2016), a domestic flight schedule at Lombok Praya International Airport can be obtained. Based on this data, it can be seen there are five airlines who operating there, namely Garuda Indonesia, Citilink, Batik Air, Wings Air, and Lion Air.

To determine the number of passengers per hour, the data load factor, aircraft capacity, and the percentage of passengers transported, must be known first. For domestic flights, passengers can check-in 2 hours to 45 minutes before the scheduled departure, so that the peak hour occurs within three hours (06.00-09.00 a.m. on Friday). Based on the flight schedule, it was found that the peak hour of the check-in process took place at 05.00 to 06.00 a.m. with 471 passengers per hour in 2016 and 1,214 passengers per hour in 2036. These number of passengers will become an input in the queuing simulation on Viswalk. 


\subsection{Determination of the optimal number of check-in counters}

The number of check-in counters available at $2^{\text {nd }}$ passenger terminal of Lombok Praya International Airport is 24 counters. Therefore, it is necessary to divide the ownership of the check-in counter by calculating the percentage of the total number of passengers for each airline in 2016. Table bellows shown the result of the calculation.

Table 3. Distribution of Check-in Counters

\begin{tabular}{|l|c|c|c|c|c|c|c|c|c|c|}
\hline \multirow{2}{*}{ Airlines } & \multicolumn{7}{|c|}{ The Number of Passengers } & \multirow{2}{*}{ Total } & \multirow{2}{*}{$\%$} & $\mathrm{n}$ \\
\cline { 2 - 12 }$n n n$ \\
\hline $\begin{array}{l}\text { Garuda } \\
\text { Indonesia }\end{array}$ & 1043 & 1116 & 1043 & 1043 & 1043 & 1043 & 1116 & 7447 & $22, .53$ & 5 \\
\hline Citilink & 440 & 330 & 440 & 440 & 550 & 440 & 440 & 3080 & 9.32 & 2 \\
\hline Lion Air & 1982 & 1902 & 1982 & 2824 & 2284 & 2004 & 2133 & 15111 & 45.73 & 1 \\
1
\end{tabular}

There are three types of check-in counters used, namely priority check-in, check-in without luggage, and general check-in. The peak hour number of passengers on domestic departures in 2016 is 471 passengers per hour. By assuming the percentage of passengers for each type of check-in counter, the first scenario criteria in the following table are obtained.

Table 4. First scenario criteria

\begin{tabular}{|l|c|c|c|c|}
\hline \multirow{2}{*}{ Type of Check-in } & \multirow{2}{*}{ Percentage } & $\begin{array}{c}\text { Number of } \\
\text { Passengers }\end{array}$ & Service Duration & Median \\
\cline { 4 - 5 } & & 47 & $1.00-3.00$ & 2.0 \\
\hline Priority Check-in & $10 \%$ & 141 & $1.00-3.00$ & 2.0 \\
\hline Check-in without Luggage & $30 \%$ & 283 & $1.00-6.00$ & 3.5 \\
\hline General Check-in & $60 \%$ & &
\end{tabular}

Table 5. The number of passengers each Airline in 2016

\begin{tabular}{|c|c|c|c|c|c|c|c|}
\hline \multirow[b]{2}{*}{ Type of Check-in } & \multicolumn{6}{|c|}{ The Number of Passengers } & \multirow[b]{2}{*}{ Total } \\
\hline & $\begin{array}{c}\text { Garuda } \\
\text { Indonesia }\end{array}$ & Citilink & $\begin{array}{c}\text { Lion } \\
\text { Air }\end{array}$ & $\begin{array}{c}\text { Batik } \\
\text { Air }\end{array}$ & $\begin{array}{c}\text { Wings } \\
\text { Air }\end{array}$ & Others & \\
\hline Priority Check-in & 10 & 0 & 0 & 6 & 0 & 0 & 16 \\
\hline $\begin{array}{l}\text { Check-in without } \\
\text { Luggage }\end{array}$ & 30 & 16 & 65 & 19 & 11 & 0 & 141 \\
\hline General Check-in & 60 & 37 & 154 & 37 & 26 & 0 & 315 \\
\hline
\end{tabular}

The determination of the optimal number of check-in counters opened by each airline is conducted iteratively through Viswalk with the results in the table below.

Table 6. The number of check-in counters used in 2016

\begin{tabular}{|c|c|c|c|c|c|c|c|}
\hline \multirow[b]{2}{*}{ Type of Check-in } & \multicolumn{6}{|c|}{ Number of Check-in Counters } & \multirow[b]{2}{*}{ Total } \\
\hline & $\begin{array}{c}\text { Garuda } \\
\text { Indonesia }\end{array}$ & Citilink & $\begin{array}{c}\text { Lion } \\
\text { Air }\end{array}$ & $\begin{array}{l}\text { Batik } \\
\text { Air }\end{array}$ & $\begin{array}{c}\text { Wings } \\
\text { Air }\end{array}$ & Others & \\
\hline Priority Check-in & 1 & 0 & 0 & 1 & 0 & 0 & 2 \\
\hline Check-in without Luggage & 1 & 1 & 2 & 1 & 1 & 0 & 6 \\
\hline Priority Check-in & 3 & 1 & 6 & 1 & 1 & 1 & 13 \\
\hline Total & 5 & 2 & 8 & 3 & 2 & 1 & 21 \\
\hline
\end{tabular}

While in the second scenario, iteration of the number of check-in counters is done with 1,214 passengers per hour and follows the criteria below. 
Table 7. Second scenario criteria

\begin{tabular}{|l|c|c|c|c|}
\hline \multirow{2}{*}{ Type of Check-in } & Percentage & $\begin{array}{c}\text { Number of } \\
\text { Passengers }\end{array}$ & Service Duration & Median \\
\cline { 4 - 5 } & & 122 & $1.00-3.00$ & 2.0 \\
\hline Priority Check-in & $10 \%$ & 364 & $1.00-3.00$ & 2.0 \\
\hline Check-in without Luggage & $30 \%$ & 728 & $1.00-6.00$ & 3.5 \\
\hline General Check-in & $60 \%$ & \multicolumn{2}{|c}{} \\
\hline
\end{tabular}

Table 8. The number of passengers each airline in 2016

\begin{tabular}{|l|c|c|c|c|c|c|c|}
\hline \multirow{2}{*}{ Type of Check-in } & \multicolumn{6}{|c|}{ The Number of Passengers } & \multirow{2}{*}{ Total } \\
\cline { 2 - 8 } & $\begin{array}{c}\text { Garuda } \\
\text { Indonesia }\end{array}$ & Citilink & $\begin{array}{c}\text { Lion } \\
\text { Air }\end{array}$ & $\begin{array}{c}\text { Batik } \\
\text { Air }\end{array}$ & $\begin{array}{c}\text { Wings } \\
\text { Air }\end{array}$ & Others & \\
\hline Priority Check-in & 26 & 0 & 0 & 16 & 0 & 0 & 42 \\
\hline Check-in without Luggage & 77 & 41 & 169 & 48 & 29 & 0 & 364 \\
\hline General Check-in & 154 & 95 & 395 & 96 & 68 & 0 & 808 \\
\hline
\end{tabular}

Due to the high demand of passengers, the self-service check-in facility is required in 2036 to serve passengers without baggage with the results in the table below.

Table 9. The number of check-in counters used in 2036

\begin{tabular}{|c|c|c|c|c|c|c|c|}
\hline \multirow[b]{2}{*}{ Type of Check-in } & \multicolumn{6}{|c|}{ Number of Check-in Counters } & \multirow[b]{2}{*}{ Total } \\
\hline & $\begin{array}{c}\text { Garuda } \\
\text { Indonesia }\end{array}$ & Citilink & $\begin{array}{l}\text { Lion } \\
\text { Air }\end{array}$ & $\begin{array}{l}\text { Batik } \\
\text { Air }\end{array}$ & $\begin{array}{l}\text { Wings } \\
\text { Air }\end{array}$ & Others & \\
\hline Priority Check-in & 1 & 0 & 0 & 1 & 0 & 0 & 2 \\
\hline Check-in without Luggage & 0 & 0 & 0 & 0 & 0 & 0 & 0 \\
\hline Priority Check-in & 4 & 2 & 11 & 2 & 2 & 1 & 22 \\
\hline Total & 5 & 2 & 11 & 3 & 2 & 1 & 24 \\
\hline
\end{tabular}

Table 10 .The number of self-service check-in machines used in 2036

\begin{tabular}{|l|c|c|c|c|c|c|c|}
\hline \multirow{2}{*}{ Type of Check-in } & \multicolumn{5}{|c|}{ Number of Self Service Check-in Machines } & \multirow{2}{*}{ Total } \\
\cline { 2 - 7 } & $\begin{array}{c}\text { Garuda } \\
\text { Indonesia }\end{array}$ & Citilink & $\begin{array}{c}\text { Lion } \\
\text { Air }\end{array}$ & $\begin{array}{c}\text { Batik } \\
\text { Air }\end{array}$ & $\begin{array}{c}\text { Wings } \\
\text { Air }\end{array}$ & Others & \\
\hline Priority Check-in & 0 & 0 & 0 & 0 & 0 & 0 & 0 \\
\hline Check-in without Luggage & 3 & 2 & 5 & 2 & 1 & 0 & 13 \\
\hline Priority Check-in & 0 & 0 & 0 & 0 & 0 & 0 & 0 \\
\hline Total & 3 & 2 & 5 & 2 & 1 & 0 & 13 \\
\hline
\end{tabular}

\subsection{Queuing simulation in 2016 and 2036}

The analysis of check-in counter queue at $2^{\text {nd }}$ passenger terminal of Lombok Praya International Airport is done by simulation of Viswalk for each type of airline. In queuing simulation, applied the arrival rate and number of check-in counters that have been obtained previously. This simulation is done three times within one hour real time. However, the simulation will stop immediately when the time runs out, so that not all passengers can be served. Passenger movement starts from the x-ray security area, then goes into the check-in area, and ends on the $2^{\text {nd }}$ floor. There are two types of routes used, namely static and partial. Static routes are used to set start and end points. While the partial route serves to distribute passengers randomly on the check-in counter. The image below shows the check-in area at $2^{\text {nd }}$ passenger terminal of Lombok Praya International Airport. 


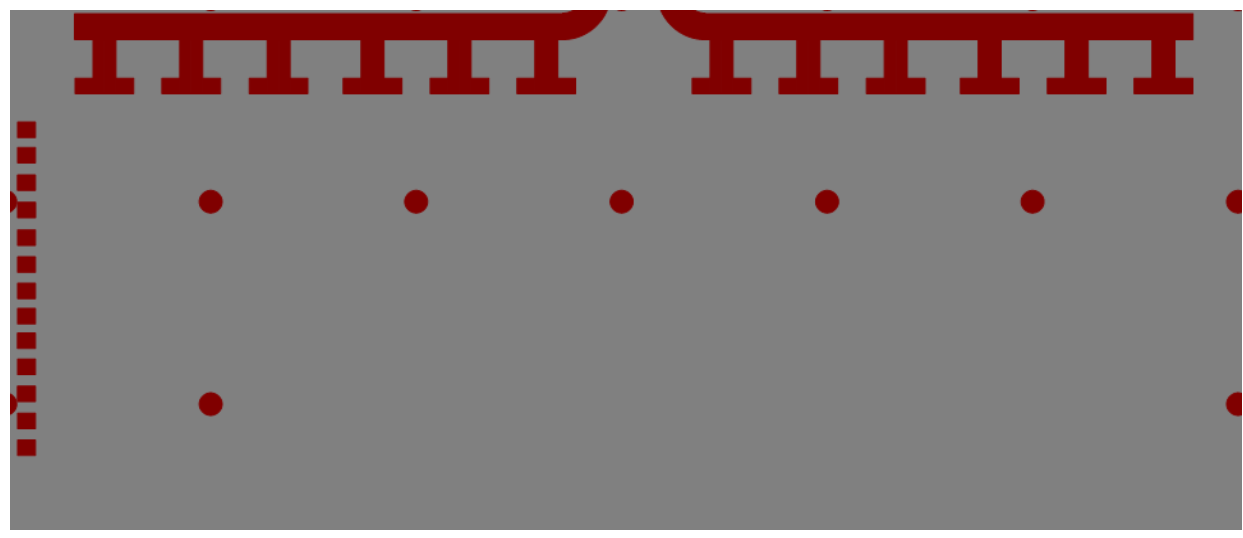

Fig. 2. Model of check-in area for simulation

Table 11 below shows the example of queuing parameters of Garuda Indonesia in 2016 as the result of simulation using Viswalk. There are four queueing parameters to be reviewed in this paper, i.e. number of passengers in the system, number of passengers in the queue, passenger's duration in the system, and passenger's duration in the queue.

Table 11. Queuing parameters of Garuda Indonesia in 2016

\begin{tabular}{|l|c|c|c|c|c|c|c|}
\hline \multirow{3}{*}{$\begin{array}{c}\text { Type of } \\
\text { Check-in }\end{array}$} & \multirow{2}{*}{$\begin{array}{c}\text { Number of } \\
\text { Passengers }\end{array}$} & \multirow{2}{*}{$\begin{array}{c}\text { Number } \\
\text { of }\end{array}$} & \multicolumn{2}{|c|}{$\begin{array}{c}\text { Average Number of } \\
\text { Passengers }\end{array}$} & \multirow{2}{*}{ Passengers' Duration } & $\begin{array}{c}\text { Average } \\
\text { Service }\end{array}$ \\
\cline { 5 - 7 } & Counters & System & Queue & System & Queue & Duration \\
\cline { 5 - 8 } & (persons) & & (persons) & (persons) & (minutes) & (minutes) & (minutes) \\
\hline Priority & 10 & 1 & 2 & 1 & 2,05 & 0,09 & 1,96 \\
\hline No Luggage & 30 & 3 & 3 & 2 & 3,43 & 1,53 & 1,90 \\
\hline General & 60 & 6 & 5 & 4 & 10,46 & 6,69 & 3,09 \\
\hline Total & 100 & 10 & 10 & 7 & & & \\
\hline
\end{tabular}

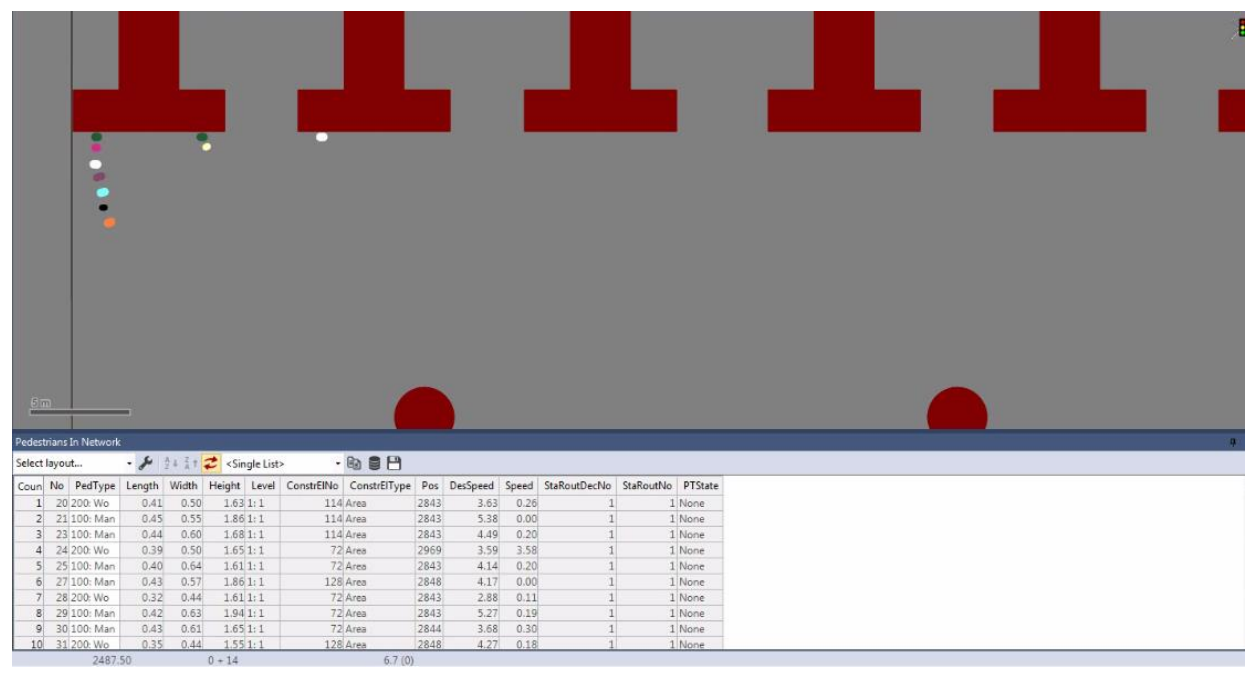

Fig.3. Example of queuing simulation using viswalk 
From the simulation and analysis of check-in queue, the comparison of arrival rate and service levels of passengers in 2016 and 2036 is shown in the table below.

Table 12. Comparison of arrival and service levels of check-in counter in 2016

\begin{tabular}{|c|c|c|c|c|c|c|c|c|}
\hline \multirow{2}{*}{ Airlines } & \multirow{2}{*}{ Type of Check-in } & \multirow{2}{*}{$\begin{array}{l}\text { Number of } \\
\text { Passengers }\end{array}$} & \multicolumn{3}{|c|}{$\begin{array}{c}\text { Arrival Rate } \\
\text { (Passengers/ Hour) }\end{array}$} & \multicolumn{3}{|c|}{$\begin{array}{l}\text { Level of Service } \\
\text { (Passengers/Hour) }\end{array}$} \\
\hline & & & $1^{\text {st }}$ & $\begin{array}{l}2^{\text {nd }} \\
\text { Sim }\end{array}$ & $\begin{array}{l}3^{\text {rd }} \\
\text { Sim }\end{array}$ & $\begin{array}{l}1 \text { st } \\
\text { Sim }\end{array}$ & $\begin{array}{l}\text { 2nd } \\
\text { Sim }\end{array}$ & $\begin{array}{l}\text { 3rd } \\
\text { Sim }\end{array}$ \\
\hline \multirow{4}{*}{$\begin{array}{l}\text { Garuda } \\
\text { Indonesia }\end{array}$} & Priority & 10 & 6 & 10 & 7 & 5 & 9 & 7 \\
\hline & Without Luggage & 30 & 22 & 28 & 22 & 20 & 24 & 20 \\
\hline & General & 60 & 49 & 52 & 56 & 35 & 35 & 36 \\
\hline & Total & 100 & 77 & 90 & 85 & 60 & 68 & 63 \\
\hline \multirow{3}{*}{ Citilink } & Without Luggage & 16 & 9 & 14 & 10 & 9 & 14 & 10 \\
\hline & General & 37 & 29 & 34 & 30 & 13 & 16 & 15 \\
\hline & Total & 53 & 38 & 48 & 40 & 22 & 30 & 25 \\
\hline \multirow{3}{*}{$\begin{array}{l}\text { Wings } \\
\text { Air }\end{array}$} & Without Luggage & 11 & 9 & 11 & 7 & 6 & 11 & 7 \\
\hline & General & 26 & 19 & 23 & 19 & 12 & 15 & 14 \\
\hline & Total & 37 & 28 & 34 & 26 & 18 & 26 & 21 \\
\hline \multirow{4}{*}{ Batik Air } & Priority & 6 & 2 & 4 & 5 & 2 & 4 & 4 \\
\hline & Without Luggage & 19 & 13 & 14 & 12 & 13 & 14 & 12 \\
\hline & General & 37 & 29 & 34 & 30 & 13 & 16 & 15 \\
\hline & Total & 62 & 44 & 52 & 47 & 28 & 34 & 31 \\
\hline \multirow{3}{*}{ Lion Air } & Without Luggage & 65 & 30 & 38 & 38 & 23 & 30 & 27 \\
\hline & General & 154 & 131 & 130 & 150 & 76 & 78 & 80 \\
\hline & Total & 219 & 161 & 168 & 188 & 99 & 108 & 107 \\
\hline
\end{tabular}

Table 13. Comparison of arrival and service levels of check-in counter in 2036

\begin{tabular}{|c|c|c|c|c|c|c|c|c|}
\hline \multirow{2}{*}{ Airlines } & \multirow{2}{*}{ Type of Check-in } & \multirow{2}{*}{$\begin{array}{l}\text { Number of } \\
\text { Passengers }\end{array}$} & \multicolumn{3}{|c|}{$\begin{array}{c}\text { Arrival Rate } \\
\text { (Passengers/ Hour) }\end{array}$} & \multicolumn{3}{|c|}{$\begin{array}{l}\text { Level of Service } \\
\text { (Passengers/Hour) }\end{array}$} \\
\hline & & & $\begin{array}{l}1^{\text {st }} \\
\text { Sim }\end{array}$ & $\begin{array}{l}2^{\text {nd }} \\
\text { Sim }\end{array}$ & $\begin{array}{l}3^{\text {rd }} \\
\text { Sim }\end{array}$ & $\begin{array}{r}1 \text { st } \\
\text { Sim }\end{array}$ & $\begin{array}{l}\text { 2nd } \\
\text { Sim }\end{array}$ & $\begin{array}{l}\text { 3rd } \\
\text { Sim }\end{array}$ \\
\hline \multirow{4}{*}{$\begin{array}{l}\text { Garuda } \\
\text { Indonesia }\end{array}$} & Priority & 26 & 19 & 21 & 19 & 18 & 18 & 18 \\
\hline & Without Luggage & 77 & 54 & 57 & 14 & 58 & 63 & 65 \\
\hline & General & 154 & 128 & 130 & 149 & 52 & 52 & 55 \\
\hline & Total & 257 & 201 & 208 & 182 & 128 & 133 & 138 \\
\hline \multirow{3}{*}{ Citilink } & Without Luggage & 41 & 32 & 37 & 40 & 30 & 34 & 30 \\
\hline & General & 95 & 82 & 86 & 89 & 27 & 29 & 27 \\
\hline & Total & 136 & 114 & 123 & 129 & 57 & 63 & 57 \\
\hline \multirow{3}{*}{$\begin{array}{l}\text { Wings } \\
\text { Air }\end{array}$} & Without Luggage & 29 & 22 & 26 & 22 & 20 & 21 & 20 \\
\hline & General & 68 & 59 & 61 & 65 & 26 & 28 & 28 \\
\hline & Total & 97 & 81 & 87 & 87 & 46 & 49 & 48 \\
\hline \multirow{4}{*}{ Batik Air } & Priority & 16 & 12 & 14 & 10 & 12 & 14 & 10 \\
\hline & Without Luggage & 48 & 37 & 44 & 48 & 36 & 38 & 38 \\
\hline & General & 96 & 82 & 86 & 89 & 27 & 29 & 27 \\
\hline & Total & 160 & 131 & 144 & 147 & 75 & 81 & 75 \\
\hline \multirow{3}{*}{ Lion Air } & Without Luggage & 169 & 137 & 147 & 171 & 118 & 115 & 125 \\
\hline & General & 395 & 377 & 351 & 372 & 177 & 168 & 176 \\
\hline & Total & 564 & 514 & 498 & 543 & 295 & 283 & 301 \\
\hline
\end{tabular}




\subsection{Solutions for increasing number of passengers}

There are several ways to minimize the queue at check-in counter, one of them is providing the self-service check-in facility, as an alternative for passengers to check-in at the airport terminal. Passengers simply enter the reference booking number or scan the barcode printed on the itinerary, then print the boarding pass.

However, the availability of self-service check-in facility at airports in Indonesia is still lacking. There are only a few airlines that have provided such facility, such as Citilink, Air Asia, and Garuda Indonesia. In fact, the use of this facility can give some benefits for passengers, including:

- Easy to use and understand by passengers;

- A faster check-in process;

- Control held completely by passengers;

- No need to queue at the check-in counter;

- Reduce passengers' waiting time in queue;

- Passengers can choose the desired seat number.

For the airlines, the use of self-service check-in can lower the operating costs and increase revenue, while improving passenger services. This facility can provide good influences for the airline with the following reasons.

- Passenger queues on the queue line of check-in counters are fewer;

- Cheaper for long-term operations;

- Reduce the need of officers, equipment, and new check-in counter;

- Reduce operational costs;

- Serving the needs of passengers, especially during peak hours;

- Eliminated the unnecessary interactions between officers and passenger who does not need help anymore.

Other check-in service which currently developing is city check-in. This facility has been implemented in various big airports in the world, such as Hong Kong and Singapore. In Indonesia, city check-in only provided in Jakarta for several airlines, for example Garuda Indonesia. City check-in facility allow passengers to check-in at the city center, such as at certain airline marketing offices. Passengers can hand their luggage to the officer, and later the baggage will be delivered directly to the airport. Generally, city check-in opens 48 to 4 hours before the scheduled departure time.

By providing city check-in facility in Lombok, passengers do not need to come in a hurry to the airport and can enjoy the tour much longer. Therefore, this facility can reduce the check-in queue at $2^{\text {nd }}$ passenger terminal of Lombok Praya International Airport.

\section{Conclusions}

- The annual passenger movement for domestic departure in 2016 is 1,213,051 passengers. While in 2036, passenger movement is forecast to increase to $3,121,722$ passengers per year.

- Check-in counter opens from 2 hours to 45 minutes before the scheduled departure time. Peak hour occurs at 05.00-06.00 a.m. with the number of passengers in 2016 is 471 passengers per hour, and increased to 1,214 passengers per hour in 2036.

- The optimum number of check-in counters opened to serve the peak hour passengers in 2016 is twenty-one. While in 2036, it takes a total of twenty-four counters for priority check-in and general check-in, and thirteen self-service check-in machines.

- There are several attempts to minimize the check-in queue, among which are: 
- Provides self-service check-in facility which would be better if equipped with an auto bag drop;

- Provides city check-in services.

\section{Acknowledgement}

Most of the data and analysis contained in this paper have basically been presented in first author's final paper (unpublished) in Civil Engineering Program in Bandung Institute of Technology under second author supervision. More detailed work can be obtained in university's electronic library.

\section{References}

1. Statistic Indonesia (BPS) of West Nusa Tenggara Province: Nusa Tenggara Barat in Figures (2008-2016)

2. Ashford, N. J., Mumayiz, S.A. \& Wright, P.H. Planning, Design, and Development of 21st-Century Airports 4th (2011)

3. Oktorina, Yurika. Analisis Pergerakan Penumpang di Dalam Terminal I-A Bandar Udara Soekarno Hatta. Thesis for Master Degree with Transportation Specificity, Universitas Indonesia (2012)

4. Marten, J.B. \& Henningsson, J. "Verification and Validation of Viswalk for Building Evacuation Modelling" (2012)

5. National Standardization Agency (BSN). Standar Nasional Indonesia (SNI) 037046-2004 tentang Terminal Penumpang Bandar Udara. (2004)

6. $\quad$ PTV (Planung Transport Verkehr). PTV Vissim 8 User Manual. (2014) 